\title{
"ITU SEBUAH SKANDAL": LEXICAL AND SOCIOCULTURAL INTERPRETATION IN CRITICAL DISCOURSE ANALYSIS OF FADLI ZON'S TWEET
}

\author{
Joice Yulinda Luke ${ }^{1 *}$; Monika Widyastuti Surtikanti²; Sumarlam³ \\ ${ }^{1}$ Language Center, English Department, Faculty of Humanities, Bina Nusantara University \\ Jl. Kemanggisan Illir III No. 45, Palmerah, Jakarta 11480, Indonesia \\ ${ }^{2}$ English Language Education Study Program, STKIP Pamane Talino \\ Jl. Afandi Rani, Jalur II, Desa Raja, Landak, Kalimantan Barat 79357, Indonesia \\ ${ }^{1,2}$ Linguistics Doctoral Program of Universitas Sebelas Maret Surakarta \\ Jl. Ir. Sutami No. 36, Kentingan, Surakarta, Jawa Tengah 57126, Indonesia \\ ${ }^{3}$ Faculty of Cultural Sciences, Universitas Sebelas Maret \\ Jl. Ir. Sutami No. 36, Kentingan, Surakarta, Jawa Tengah 57126, Indonesia \\ 1joice.luke@binus.ac.id; 2monikawidy72@gmail.com; 33umarlam@staff.uns.ac.id
}

Received: $08^{\text {th }}$ January 2021/ Revised: $28^{\text {th }}$ February 2021/ Accepted: $01^{\text {st }}$ March 2021
How to Cite: Luke, J. Y., Surtikanti, M. W., \& Sumarlam. (2021). "Itu sebuah skandal”: Lexical and sociocultural interpretation in critical discourse analysis of Fadli Zon's tweet. Humaniora, 12(1), 53-59.
https://doi.org/10.21512/humaniora.v12i1.6907

\begin{abstract}
There were two objectives of the research. The first was to analyze the word 'scandal' from textual analysis (micro-level) and sociocultural analysis (macro-level). To analyze the findings, the research made use of Norman Fairclough's model as the basis of critical discourse analysis. The research was qualitative, which tended to use inductive as the approach. There were 23 informants who participated in the survey and the FGD. They were selected purposively based on their profession and the workplace areas. The data were the four of Fadli Zon's tweets containing the word 'scandal'and its context, which was available in some online media. Research content based on the textual analysis (microanalysis) shows that the text structure is short and directly conveys Fadli Zon's criticism or negative assumptions toward any policies of government issues. Besides, the macro analysis indicates Fadli Zon has a dominant power to utter the negative judgments toward the government regarding the position in the government structure as one of the leaders in the Indonesian House of Representative. Substantially, the use of specific terms'scandal'overall illustrates the negative opinions and indicating declining trust in the policymakers on certain governmental issues. The use of cynicism, sarcasm, and satire styles colors Fadli Zon's tweets that are also accompanying the overused of 'scandal' word. The analysis based on the dimension of discourse practice (micro-level) indicates that using the word 'scandal' in Fadli Zon's tweets is cynical according to the public opinions. The analysis based on the social-cultural practice dimension (macro-level) indicates that Fadli Zon is one Indonesian politician who is often opposed to the Indonesian government policies.
\end{abstract}

Keywords: scandal interpretation, lexical interpretation, sociocultural interpretation, critical discourse analysis

\section{INTRODUCTION}

The presence of social media as a source of information has greatly influenced the pattern of social interaction between individuals. It reflects the various statements, either good or bad, on certain issues in order to gain social reactions from netizens or readers of social media from being a means of communicating in cyberspace. Social media is classified as new media that can be used as an effort to present one's self-image, including for politicians. Therefore, many politicians have used social media to introduce themselves or indicating their political views.

Interestingly, most of the government 
opponents often involve conflicting points of view with government officials through social media like Twitter. Twitter has been utilized not only for building communication or networking but also for striking other parties' policies or statements, especially during election campaigns, as well as promoting new policies of the government. It is mostly due to the fact that the platform has frequently replaced the traditional modes of political communication (Himelboim, Mccreery, \& Smith, 2013; Hsu, Park, \& Park, 2013; Masroor et al., 2019). Criticisms toward new regulations or any other government issues are often applied by politicians and members of the House of Representatives in Indonesia. Fadli Zon, a politician from the Gerindra party, also known as the Vice Chairman of House of Representative from 2014 through 2019, often conveys his opposite political views or opinions about government policies even to regulations by $\mathrm{Mr}$. Jokowi, the President of Indonesia, via his Twitter. Interestingly, he often uses the word 'scandal' in his tweets.

According to Kamus Besar Bahasa Indonesia (Indonesian Dictionary), the word 'scandal' defines as perbuatan yang memalukan; perbuatan yang menurunkan martabat seseorang (embarrassing action, damage to reputation). It means that the word 'scandal' has a negative connotation since it refers to bad, embarrassing, and improper action. Politicians often use certain diction in the discourse to persuade their followers and build political issues in a particular situation. This is in line with Hague et al. (in Masroor et al., 2019), saying that politics involves resolving conflict by using persuasion, where language acts as a primary and significant tool. Thus, linguistics features should be the basis of the discourse analysis to convey the message delivered by the politicians. The analysis should also involve the public as the readers of the discourse being uttered when the context, 'functions and implications' of their communication is, in essence, political (Van Dijk, 1997). Therefore, it is necessary to study this phenomenon using critical discourse analysis.

Discourse is defined as a statement. As stated by Kusno and Bety (2017), discourse is considered as a bigger linguistic unit than a word or sentence involving one person or even more. Sumarlam (2016) has stated that discourse is a set of complete language implied, both spoken and written, viewed from the micro and macrostructure. The microstructure is viewed from the cohesive; meanwhile, the macrostructure is viewed from the coherency of the meaning. Discourse is very close to our daily life. It can be seen in the conversation, interview, speech, writing, article, announcement, etc. Discourse means a set of utterances, sentences, or statements, which is delivered in a public setting, and it directly contributes to the social context (Manan, 2019). Thus, discourse can be defined as a set of linguistic units, which is delivered in the public setting, both spoken and written, and it has impacts on the social context.

Language context can be deeply understood using discourse analysis. Van Djik has categorized three elements in analyzing discourse: language use, communication, and interaction (Suciartini, 2017). It is due to the thing that discourse involves not only the linguistic perspective but also social and philosophical as well. Stef Slembrouck has classified discourse analysis into eight approaches: philosophical, linguistic, linguistic anthropological, cultural studies, post-structuralism, social theory, and sociology (Purbani, 2009). It is in line with Fauzan (2014), which concludes some theories of discourse analysis and the correlation toward the social practice. It is believed that social phenomena correlate to linguistics. Linguistics is a part of social phenomena as linguistic cannot be separated from the effect of the social environment. Meanwhile, social phenomena frequently involve linguistic activity. Discourse analysis observes the context within the communication between addressee and addresser, situation or context, the different types of communication development, and the correlation of each party (Guy Cook in Eriyanto, 2001).

Discourse analysis has some studies viewed from the purpose of the analysis. One of them is critical discourse analysis (CDA). CDA is a linguistic area where both spoken and written text is analyzed to explore the discursive sources of power, dominance, inequality, and bias (Manan, 2019). Language is related to the context since it represents a particular subject, topic, and discourse in CDA (Sumarlam, 2016). Jorgensen and Phillips (2002) have stated that CDA is a combination of theories and methods in the case of discourse, social, and cultural development in the different social domains. The characteristics of CDA consist of action, context, history, power, and ideology (Fairclough, 2003; Van Dijk, 2008; Sumarlam, 2016).

Discourse action is defined as a conscious and controlled interactive form, which is delivered for a particular purpose. As Ahmadvand in Fairlough (1995) has denoted that CDA is any theory concerned with the critique of ideology and the effects of domination. Thus, context is the most crucial part of CDA since it has a role as the connector between text and context. Van Dijk (2008) has divided into three elements: setting, participant, and communication event. CDA should consider the context, time, place, and connection to the past and future issue. Participant refers to who is involved in the event in terms of its identity, role, power, and ideology (Fairclough, 1992; Eriyanto, 2001; Sumarlam, 2016).

Concerning CDA, Fairclough (1992) has offered a CDA model that contains three dimensions, namely: text, discursive practice, and social practice. The three dimensions have their process and territory. Text dimension focuses on the use of language to analyze the themes and ideology. The use of the language covers lexical, metaphor, and sentence structure (Sumarlam, 2016). Discursive practice relates to the interaction of texts with individuals or communities in the form of production processes and interpretations (Manan, 2019). Text interpretation is carried out through four elements: the surface of utterance, the 
meaning of the utterance, local coherence, and unity of discourse (Sumarlam, 2016). The third dimension is a social practice which is defined as the analysis of the relationship between discourse and social context. The analysis aims at seeking the explanation of the result of interpretation in the description and interpretation stages. The description is used to analyze text, then the interpretation is used to analyzed the production process and interpretation of the text, and the explanation is used to analyze socio-cultural practices, including situational, institutional, and social levels (Fairclough, 1992).

There are some studies related to CDA with Norman Fairclough's model. The first is Sumarlam (2016), which analyzed news text about internal conflict in Yogyakarta Palace, consisting of text analysis, interpretation, and social practice. Sumarlam has stated that the structure of the news is built by four units, namely headline, orientation, a sequence of events, and closing. There is positive and negative ideology, namely the positive ideology of the conflicting sides. The institutions (government, experts) are represented through modalities and positive sentences. It then constitutes to Badara (2012) that has stated that, positively, an ideology is a worldview that states the value of certain social groups to defend and develop their interests. In other words, in every discourse, there is an ideology that dominates and seizes the influences.

In contrast, the hostile ideology is represented through prohibition and negative sentences. Risdianto, Sumarlam, and Santosa (2019) in Badara (2012) have also stated that the situation where the news text is produced, the institution's involvement, and the people of Yogyakarta Palace are correlated with economic, political, and social-cultural issues, which can be explained by their socio-cultural context. Having the same model of CDA, Manan (2019) has analyzed news text in the online newspaper, Jakarta Post, about President Jokowi's utterance stating the term 'sontoloyo' and 'genderuwo'. The result of CDA reveals that the news text has various interpretations. The situation where the news is produced in the President General Election in Indonesia. The present research analyzes four of Fadli Zon's tweets cited by four online media using Norman Fairclough's model.

The previous research related to CDA on the tweet is from Kusno \& Bety's (2017) research. They have analyzed Fahri Hamzah's tweet regarding the issue on the Right of Inquiry of Corruption Eradication Commission (KPK) proposed by the House of Representative (DPR). The aim is to evaluate KPK's work. However, this action is opposed by many people in Indonesia and result in a controversial issue. People argue that this action would spend 3,1 billion rupiahs of the government budget. In addition, there is a fear of emerging a conflict of interest between DPR and KPK. Fahri Hamzah, a vice chairman of the House of Representatives, is the one who actively promotes the right of inquiry to KPK. He delivers his perception toward this issue through Twitter. The result of
CDA using Fairclough's model reveals that the text represents various perceptions of Fahri Hamzah. The use of vocabulary illustrates the opposing opinion and pessimism related to the performance of KPK. The use of cynicism, sarcasm, and satire styles colors the entire Fahri's tweets. Different from the previous research, the present research focuses on the diction 'skandal' used by Fadli Zon in his four tweets. The research is expected to facilitate the knowledge of online textanalysis as well as helps readers be critical and being proportional in interpreting the political messages conveyed by the online news.

\section{METHODS}

The research is qualitative, which tends to use inductive as the approach. There are 23 informants who participate in the survey and the FGD. They are selected purposively based on their profession and the workplace areas. The data are the four Fadli Zon's tweets containing the word 'scandal' and its context, which is available in some online media, namely jateng.tribunnews.com, tajuk.co, suara.com, and twitter.com. The research methods cover (1) the linguistic description viewed from semantic analysis on the word 'scandal' and its context containing the four Fadli Zon's tweets; (2) the analysis of the relationship between the context of the tweet within the socio-cultural. To analyzing the data collection, the researchers employ the triangulation method from informants' responses on the distributed online questionnaire and Focus Group Discussion (FGD) to validate the questionnaire data. The procedure includes reviewing the text, take note of significant features, analyzing and developing the analysis (Mackey \& Gass, 2012).

Also, the researchers use three dimensions in Fairclough's model (1992), which consists of text analysis (micro-level), discursive practice (meso level), and social practice (macro-level). Each dimension has its own territory and process, and they are interrelated. The text analysis relates to the result of the production process. The discursive practices relate to the interaction of texts with individuals or communities in the form of production processes and interpretations. The social practice or context includes socio-cultural practices in which the production process and interpretation take place. Then, the three dimensions are then analyzed with three different analysis models. The researchers use description to analyze text. The text is in the form of a tweet, which is a short text. In this process, the researchers describe the tweets containing the word 'scandal' followed by the context. Interpretation is used to analyze the production process and interpretation of the text. In this process, the researchers focus on the lexical analysis of the word 'scandal'. The analysis involves the meaning of the word in the dictionary and the context and situation in which the word is uttered. The explanation is used to analyze socio-cultural practices 
that include situational, institutional, and social levels (Fairclough, 1992). The researchers analyze the public's opinion toward Fadli Zon's tweets.

The research focuses on the micro-level, which covers analysis on the lexis 'scandal' presented in the four Fadli Zon's tweets; and macro level, which covers situational, institutional, and social. The situational level deals with the context where the tweets are being produced; the institutional level deals with the impact of the institution's power; while the social level deals with the cultural issue in society as the impact of the tweets.

\section{RESULTS AND DISCUSSIONS}

As stated in the previous section, the researchers present the analysis by analyzing the text and the context at the micro-level and explaining the social practices that cover situational, institutional, and social levels in the macro level based on Fairclough's model (1992). The followings are the result of the analysis of Fadli Zon's (FZ) tweets containing the word 'scandal'.

In the micro analysis (textual analysis), first, the researchers will describe from the text analysis. Generally, the generic structure of a text is divided into three parts, namely, opening, central, and closing (Kusno \& Bety, 2017). Since the text is in the form of a tweet, thus the generic structure covers opening and closing. The speech act implies directive speech (ibid). Besides, the content deals with Fadli Zon's assumptions on some political issues. In addressing these issues, Fadli Zon frequently uses the word 'scandal' in his tweets. First, the allegation of conflict of interest addresses the President's Special Staff.

Amid the government's efforts to deal with the impacts of pandemic Covid-19, a letter dated on 1 April 2020 from Andi Taufan Garuda, one of the President's Special Staffs, to all district heads across Indonesia leaks online and goes viral. The letter consists of some directions for the Indonesian district heads to support a Covid-19 relief program led by PT Amartha Mikro Fintek, a company he owns. This issue becomes viral and controversial since there is an allegation of conspiracy and conflict of interest within the program. Many people start to criticize this issue, including Fadli Zon. He retweets from Harun Masiku's tweet about the controversial letter saying that:

"Kalau benar, maka ini jelas sebuah skandal" (If the issue is real, then it is a scandal) (Seto, 2020).

Text (1) uses a conditional sentence. It can be identified through the word kalau (If). Based on Cambridge Dictionary (2016), a conditional sentence is used to express the possible result of an imagined situation in the present or future time. In this case, Fadli Zon assumes there is a conflict of interest regarding the appointment of PT Amartha Mikro Fintek as the company partner for the government's project.
Next, the issue is on China workers. The second tweet of Fadli Zon containing the word 'scandal' is regarding the rumor on the government's plan to allow 500 China workers to enter the country amid the pandemic Covid-19. This rumour has ignited debates and criticism in Indonesia. As the opposition party, Fadli Zon criticizes this rumor by writing the tweet:

"Ini jelas sebuah skandal, di tengah wabah virus corona, masih ada pihak2 yg membawa masuk TKA dr daerah terdampak dg cara diam 2 lewat belakang. Informasinya pun simpang siur. Sebaiknya kembalikan TKA tersebut ke negaranya. Usut siapa di belakangnya." (This is a scandal, amid the coronavirus outbreak, some parties are trying to enter foreign workers coming from the affected areas silently. The information is confusing. They should be deported. Investigate the actor behind this) (MMU, 2020)

Text (2) is a direct statement initialed by a demonstrative determiner 'ini' (this). The demonstrative determiner is used to show the relative distance between speaker and noun (Cambridge Dictionary, 2016). Fadli Zon uses 'ini' (this) as retweeting the previous news about the issue of Chinese workers entering Indonesia. Based on the context, Fadli Zon accuses the government's involvement in the existence of foreign workers in Indonesia. In the last two sentences, Fadli Zon uses imperative sentences regarding the government's move toward the issue by saying, "Sebaiknya kembalikan TKA tersebut ke negaranya. Usut siapa di belakangnya?" (They should be deported. Investigate the actor behind this).

Then, Fadli Zon also criticizes of preemployment card program scheme. The preemployment card program is one of the government's programs as the impact on the social-economic aspect during Covid-19 pandemic. The government provides stimulus to strengthen social protection by increased the budget for the pre-employment card program that is officially launched on 20 March 2020 from Rp 1020 billion. The applicants of this program are limited to job seekers, terminated employees, and employees that require job competency improvement. The applicants must register online through www.prakerja. go.id starting from 11 April 2020 until 4 November 2020. This program is considered profitable for some companies. Criticism emerges from some political observers. One of them is Yunarto Wijaya, the Chief of Charta Politika. He writes on his thoughts on his Twitter:

"Pak@jokowi keterlaluan kalo anda diamkan jg skema yg sekarang... Penghematan dari 5,6 Trilyun gak kalah penting dari sekedar blusukan check bansos dah nyampe belum..."(Mr@) Jokowi, it is a nuisance if you let the scheme. Saving 5.6 billion is more crucial than merely 
blusukan, please check the social assistance).

Then, Fadli Zon has retweeted this tweet by saying:

(3) "Sy setuju kritik ini. Skema ini jelas sebuah skandal dan akan menjadi masalah hukum di waktu mendatang." (I could not agree more. This scheme is a scandal, and it will be a law problem in the future.) (Zon, 2020).

In text (3), Fadli Zon uses the agree sentence in retweeting Yunarto Wijaya's tweet by saying, "Saya setuju kritik ini" (I could not agree more). In the next sentence, he assumes that this scheme is a scandal and will cause a severe problem of law in the future.

The last is the abolition of the history subject from the Indonesian curriculum. The Ministry of Education and Culture plans to simplify the curriculum. Based on the socialization of the simplified curriculum draft, it is stated that one of the subjects being omitted is the History subject. This discourse goes viral and controversial. Fadli Zon argues that this policy is not proper, and he suggests the government to cancel it. Moreover, there is a rumor that the Sampoerna Foundation initiated the abolition of History subject. Fadli Zon comments on his Twitter by retweeting Gelora News by saying:

"Kalau pernyataan dalam berita ini benar, bahwa inisiasi penyederhanaan kurikulum yang menghapus mapel sejarah datang $d r$ Sampoerna foundation, maka ini bisa dibilang skandal. Harus segara ada klarifikasi dari MendikbudNadiem@Kemendikbud RI' (If the news is true, saying that Sampoerna Foundation initiated the curriculum simplification which to omit History subject, it will be a scandal. $\mathrm{Mr}$ Minister of education and culture, Nadiem, has to clarify it@Kemendikbud RI").

Text (4) consists of a conditional sentence. The discourse marker of this is 'kalau' (If). According to the context, Fadli Zon assumes that if the rumor is true, then it will cause a problem. He ends his sentence by delivering an imperative sentence that he wants $\mathrm{Mr}$. Nadiem to clarify the rumor.

For the lexical analysis (in micro analysis), Fairclough (1995) has stated linguistic analysis of discourse practice in the socio-cultural background is known as intertextual analysis. The linguistic analysis covers the analysis of the text at lexical, syntactic, grammatical, and vocabulary levels. To interpret the word 'scandal', the researchers use the definition from some dictionaries, namely Kamus Besar Bahasa Indonesia Versi Online (KBBI), Oxford Learner's Dictionary, Thesaurus, and Merriam Webster. KBBI defines 'scandal' as perbuatan yang memalukan; perbuatan yang menurunkan martabat seseorang (embarrassing action, damage to reputation). Oxford dictionary defines 'scandal' as behavior or an event that people think is morally or legally wrong and causes public feelings of shock or anger. Thesaurus writes 'scandal' as public embarrassment. Besides, Merriam Webster defines 'scandal' as a circumstance or action that offends propriety or established moral conceptions or disgraces those associated with it; loss of or damage to reputation caused by an actual or apparent violation of morality or propriety; malicious or defamatory gossip; and indignation, chagrin, or bewilderment brought about by a flagrant violation of morality, propriety, or religious opinion. Based on the definition from some reputable dictionaries, 'scandal' can be defined as behavior or action which is legally and morally wrong, and it can damage a reputation and cause people's anger.

The four of Fadli Zon's tweets contain the word 'scandal'. The meaning of 'scandal' in Fadli Zon's tweets is an embarrassing action that causes people's anger. In this case, the government's policy is an embarrassment and makes Indonesian people get angry. However, his judgment by saying 'scandal' is constructed above an assumption. The four of his tweets are considered as the response to the discourse that emerges within certain circumstances. The discourse needed to be clarified to make a judgment. As an opposition political actor, Fadli Zon has been delivering criticism toward the government's policy. In this case, he uses the word 'scandal' to lead people's opinion toward the Indonesian government's policy. This micro analysis has similarities to Bustan and Alakrash's (2020) analysis. They analyze the linguistics features used by Donald Trump in his tweets in which he uses some lexical such as 'radical', 'violence', 'death, and 'horror'. The use of the lexical vocabulary characterizes the Middle East countries as the land of terrorism, violence, and countries that need to be controlled. Politicians often use lexical connotes a sense of controversial, provocative, intimidating, violence, and so on to have support from the society and defend their position (ibid).

In Macro analysis, based on socio-cultural context, Fadli Zon's tweets represent his resistance toward Indonesia's government. Most of his tweets are often discussed again by some online newspapers as Tribun News, for gathering attention and measuring the interest of readers or followers of the media. This fact supports the idea on the importance of having popularity cues on the political issue as PortenCheé et al. (2018) in their research has concluded that "popularity cues can nevertheless facilitate the decision to read or watch a specific item on political issues because they point to popular content that might be worth noticing". In other words, popularity cues in online social media can affect the attitude and the knowledge of the audience on a certain political issue.

In addition, the powerful position of Fadli Zon as one of the parliament members, who well-known as an opposition politician, is assumed as an excellent strategy to increase the popularity of the online media among the netizen. Thus, in this case, it can be assumed that Fadli Zon demonstrates his private personas to 
gain empathy and recognition from his followers on Twitter. This condition reflects how social media tries to facilitate the process of setting up intimacy in politics. It is in line with Graham, Jackson, and Broersma's (2018) research that investigates how politicians are using Twitter to disclose information about their private life or personal interests/experiences.

Furthermore, Fadli Zon uses Twitter to express his ideas on certain political issues that can be viewed as a kind of propaganda. This fact is in line with Nurudin's research in 2002, as cited in Ayu (2017), which explains that politicians often perform sorts of propaganda techniques in social media. One of those techniques is Calling Names. This type of propaganda is trying to put negative labels on an individual or a specific group aiming to influence people to disagree with any previous ideas claimed by an individual or a group of government without validating the truth before.

This previous research is also coined to emphasize the current research of Sayyah and Abu (2020), who claim that "the language used by media affects our understanding and knowledge of the world". Thus, it proves that the language of media may represent ideologies or perspectives of the author. In the context of power, the usage of the 'scandal' word in Fadli Zon's tweets demonstrates unequal power between the speaker (Fadli Zon) and the followers (other Twitter users/readers). Meiristiani (2011) has found that power is a matter of the equal and unequal authority of interactant in communication. In other words, power can determine the way of communication built among interactants. The choice of words and the use of the typical term as "itu sebuah skandal" represents Fadli Zon's high dominance to his followers on Twitter. It then tries to impose others by using negative evocative words as 'skandal', 'kritik', 'keterlaluan', 'harus konfirmasi', and other excessive sentiment words. However, by exaggerating the use of negative labels as the word 'scandal', Twitter users who may be read Fadli Zon's tweets will put a negative stigma on him, as shown in Figure 1.

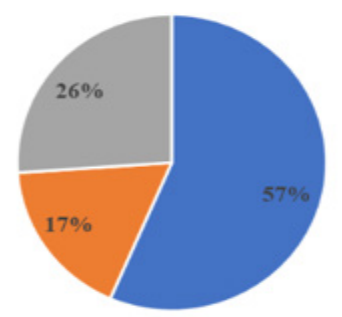

- Rubbish/Hoax/Nonsense news " Distrusted Speaker " Provocative

Figure 1 Reactions to Fadli Zon's Tweets "Itu Sebuah Skandal"

Figure 1 indicates that Fadli Zon's tweets containing the clause "Itu sebuah skandal". The findings show that the majority of readers of Fadli Zon's tweets deny believing in his statements on Twitter. More than half $(57 \%)$ of total informants react negatively to it by believing that it is rubbish, hoax, and nonsense news because there is no enough evidence to support the claims. Then, assuming one-fourth (26\%) of total participants claim the statement "Itu sebuah skandal" in Fadli Zon's tweet is provocative since everybody knows Fadli Zon is always against the government or always stands as the opponent politician. Then, there are only $17 \%$ of total informants reckon Fadli Zon as a 'distrusted speaker' because he frequently imposes government employees, even the President, with a sarcastic tone of words. Overall, most Twitter users consider Fadli Zon as someone who always has no idea what he has said, full of negative judgments based on his own assumptions, goals, and moods.

\section{CONCLUSIONS}

The effect of using 'scandal' words in Fadli Zon's tweets refers to the presupposition of the speaker (i.e., Fadli Zon) toward the context of Twitter as the communication channel. The word 'scandal' in Fadli Zon's tweets means distrusted, doubting, and alleged collusion. In addition, the meaning of the 'scandal' word can be associated with persuasion or criticism. The results of the research imply the appropriateness of diction used by politicians. Word is not a word that establishes itself; the meaning reveals many interpretations. The word 'scandal' can appear in people's interpretation and attitude. Thus, arranging suitable words in a suitable context is the best choice of a politician. Finally, since the research does not discuss in-depth the interpersonal meaning (tenor), specifically affect element which lies in these tweets. Further research is hoped to fulfill the value of this research in that area.

\section{REFERENCES}

Ayu, A. M. (2017). Peran media dalam propaganda melawan kebijakan pemerintah Amerika Serikat. International \& Diplomacy, 2(2), 265-278.

Badara, A. (2012). Analisis wacana: Teori, metode, dan penerapannya pada wacana media. Jakarta: PT Fajar Interpratama Mandiri.

Bustan, E. S., \& Alakrash, H. M. (2020). Critical discourse analysis of Donald Trump's tweets addressing the Middle Eastern countries. International Journal of Future Generation Communication and Networking, 13(2), 407-414.

Cambridge Dictionary. (2016). Cambridge dictionary. Cambridge: Cambridge University Press. Retrieved from https:/dictionary.cambridge.org/grammar/ british-grammar.

Eriyanto. (2001). Analisis wacana: Pengantar analisis teks media. Yogyakarta: LKiS Group.

Fairclough, N. (1992). Language and power (5 ${ }^{\text {th }}$ Ed.). New York: Longman Inc.

Fairclough, N. (1995). Critical discourse analysis: The 
critical study of language. New York: Longman.

Fairclough, N. (2003). Analyzing discourse: Textual analysis for social research. London: Routledge.

Fauzan, U. (2015). Analisis wacana kritis teks berita MetroTV dan TvOne mengenai luapan lumpur Sidoarjo. Surakarta: Universitas Sebelas Maret.

Graham, T., Jackson, D., \& Broersma, M. (2018). The personal in the political on Twitter: Towards a typology of politicians' personalized tweeting behavior. In Schwanholz J., Graham T., Stoll PT. (eds), Managing Democracy in the Digital Age: Internet Regulation, Social Media Use, and Online Civic Engagement (pp. 137-157). Berlin: Springer.

Himelboim, I., Mccreery, S., \& Smith, M. (2013). Birds of a feather tweet together: Integrating network and content analyses to examine cross-ideology exposure on Twitter. Journal of Computer-Mediated Communication, 18(2), 154-174. https://doi. org/10.1111/jcc4.12001.

Hsu, C., Park, S. J., \& Park, H. W. (2013). Political discourse among key Twitter users: The case of Sejong city in South Korea. Journal of Contemporary Eastern Asia, 12(1), 65-79. https://doi.org/10.17477/ jcea.2013.12.1.065.

Jorgensen, M., \& Phillips, L. J. (2002). Discourse analysis as theory and method. California: SAGE Publications.

Kamus Besar Bahasa Indonesia. (n.d.). Kamus Besar Bahasa Indonesia versi online. Retrieved from https://kbbi.web.id/skandal.

Kusno, A., \& Bety, N. (2017). Analisis wacana kritis cuitan Fahri Hamzah (FH) terkait hak angket Komisi Pemberantasan Korupsi (KPK). Ranah: Jurnal Kajian Bahasa, 6(2), 137-159. https://doi. org/10.26499/rnh.v6i2.46.

Mackey, A., \& Gass, S. M. (2012). Research methods in second language acquisition: A practical guide. New Jersey: Blackwell Publishing Ltd. https://doi. org/10.1002/9781444347340.

Manan, N. A. (2019). "Sontoloyo" and "genderuwo"; Critical discourse analysis on Jokowi's utterance. Langkawi: Journal of the Association for Arabic and English, 5(1), 55-66. http://dx.doi.org/10.31332/ lkw.v5i1.1257.

Masroor, F., Khan, Q. N.,Aib, I., \& Ali,Z. (2019). Polarization and ideological weaving in Twitter discourse of politicians. Social Media and Society, 5(4), 1-14. https://doi.org/10.1177/2056305119891220.

Meiristiani, N. (2011). Understanding tenor in spoken texts in year XII English textbook to improve the appropriacy of the texts. Indonesian Journal of Applied Linguistics, 1(1), 41-57. https://doi. org/10.17509/ijal.v1i1.98.
Merriam Webster. (2020). Merriam-Webster, Incorpoted. Retrieved from https://www.merriam-webster.com/ dictionary/scandal.

MMU. (2020). TKA China masuk Kendari, Fadli Zon: Itu skandal di tengah corona. Tajuk.co. Retrieved from https://tajuk.co/news/tka-china-masuk-kendarifadli-zon-itu-skandal-di-tengah-corona.

Oxford Learner's Dictionary. (2020).Dictionaries. Retrieved from https://www.oxfordlearnersdictionaries.com/ definition/english/scandal.

Porten-Cheé, P., Haßler, J., Jost, P., Eilders, C., \& Maurer, M. (2018). Popularity cues in online media: Theoritical and methodological perspectives. SCM Studies in Communication and Media, 7(2), 208-230. https:// doi.org/10.5771/2192-4007-2018-2-80.

Purbani, W. (2009). Analisis wacana kritis dan analisis wacana feminis. Analisis Wacana, 1, 1-5.

Risdianto, F., Sumarlam., \& Santosa, R. (2019). Representation of power in the news text of the inclusion of indigenous faiths on ID card (e-ktp). Nobel: Journal of Literature and Language Teaching, 10(2), 131-148. https://doi.org/10.15642/ NOBEL.2019.10.2.131-148.

Sayyah, A., \& Abu, A. R.. (2020). Critical discourse analysis of selected newspaper article addressing the Chapel Hill shooting incident. Journal of Communication Media Watch, 11(1) 21-34. http:// dx.doi.org/10.15655/mw/2020/v11i1/49754.

Seto, W. A. W. (2020). Stafsus presiden Andi Taufan Surati Camat, Fadli Zon: Ini jelas sebuah skandal. Tribun Jateng. Retrieved from https://jateng.tribunnews. com/2020/04/15/stafsus-presiden-andi-taufansurati-camat-fadli-zon-ini-jelas-sebuah-skandal.

Suciartini, N. N. A. (2017). Analisis wacana kritis "semua karena Ahok" program Mata Najwa Metro TV. Aksara, 29(2), 267-282. https://doi.org/10.29255/ aksara.v29i2.54.267-282.

Sumarlam, S. (2016). Representasi kekuasaan melalui sabda raja pada teks berita mengenai konflik internal Keraton Yogyakarta (Sebuah analisis wacana kritis). International Seminar Prosiding Prasasti III: Curent Research in Linguistics. pp. 58-70. https:// doi.org/10.20961/pras.v0i0.1444.

Thesaurus. (2020). Dictionary.com. Retrieved from https:// www.thesaurus.com/browse/scandal.

Van Dijk, T. A. (1997). What is political discourse analysis? Belgian Journal of Linguistics, 11(1), 11-52. https:// doi.org/10.1075/bj1.11.03dij.

Van Dijk, T. A. (2008). Discourse and context: A sociocognitive approach. Cambridge: Cambridge University Press. 